\title{
The Effects of Novel Thermal and Nonthermal Technologies on the Properties of Edible Food Packaging
}

\author{
Samira Beikzadeh ${ }^{1} \cdot$ Marjan Ghorbani $^{2} \cdot$ Nayyer Shahbazi $^{3} \cdot$ Farzaneh Izadi $^{4} \cdot$ Zahra Pilevar $^{1}$. \\ Amir Mohammad Mortazavian ${ }^{5}$
}

Received: 8 February 2020 / Accepted: 11 May 2020 / Published online: 9 June 2020

(C) Springer Science+Business Media, LLC, part of Springer Nature 2020

\begin{abstract}
Edible packaging is influenced by factors such as formulation, production technology, and solvent and additive properties. With the increase in the request for coating and film quality, appropriate form, and high product safety and storage period, various technologies such as high hydrostatic pressure, irradiation, ultrasound, high-pressure homogenization, cold plasma, and microwave have been reviewed. The present study states definitions and mechanisms of novel technologies. The experimental condition, packaging matrix, and the results pertaining to the effects of these technologies on various types of edible packaging is also discussed. The most of the matrix used for packaging was whey protein, soy protein isolate, chitosan, and gelatin. The technologies conditions such as power, frequency, time, temperature, dose, pressure, and voltage can have a significant influence on the application of them in film and coating. Therefore, finding the optimum point for the features of the technologies is important because improper use of them reduces the properties of the edible packaging.
\end{abstract}

Keywords Edible packaging $\cdot$ Film and coating $\cdot$ Nonthermal technologies $\cdot$ Mechanical properties

\section{Introduction}

Nowadays, researchers have studied the use of environmentally friendly packaging which includes natural polymers [63]. Natural polymers such as carbohydrates (chitosan, starch, alginate, celluloses, and hydrocolloids like gellan gum and seed-mucilages), lipids (waxes such as candelilla, bee, carnauba, glycerols, and fatty acids), proteins (gluten, collagen,

Amir Mohammad Mortazavian

mortazvn@sbmu.ac.ir

1 Student Research Committee, Department of Food Science and Technology, National Nutrition and Food Technology Research Institute, Faculty of Nutrition Sciences and Food Technology, Shahid Beheshti University of Medical Sciences, Tehran, Iran

2 Stem Cell Research Center, Tabriz University of Medical Sciences, Tabriz, Iran

3 Department of Food Sciences and Technology, Faculty of Agriculture, Shahrood University of Technology, Shahrood, Iran

4 Department of Food Hygiene, Faculty of Para-Veterinary Science, Bu-Ali Sina University, Hamedan, Iran

5 Department of Food Science and Technology, National Nutrition and Food Technology Research Institute, Faculty of Nutrition Sciences and Food Technology, Shahid Beheshti University of Medical Sciences, Tehran, Iran soybean, zein, and milk protein), and composites are utilized to generate novel packaging and reduce the consumption of synthetic polymers $[10,43]$. Natural polymers are further applied to various coatings and films. Coatings are spread in liquid form on the food and eaten directly while films are used in solid forms [29]. Polysaccharides and protein films have appropriate mechanical characteristics and appearances. Protein films have more impressive gas barrier properties and better mechanical characteristics owing to their unique structure and higher intermolecular connection capability compared to other films [17]. Carbohydrate films are resistant toward gas, oil, and fat, and both protein and carbohydrate films have high water vapor permeability owing to their hydrophilic behavior [91]. Lipid films, on the other hand, are resistant to moisture loss. Despite the advantages of natural polymers, they have not yet been widely applied in food manufacturing due to their relatively high cost regarding this type of packaging and weak mechanical, sensory, and barrier properties (oxygen, carbon dioxide, aroma, and water vapor) of the produced films [74].

The difference in edible film formation is related to material and additive types and properties, formulation, and film production technology. In general, materials are dissolved in acetic acid, water, alcohol, and their mixture with other solvents, and the solution is then cast and dried under optimal 
conditions. Additives such as plasticizers (for brittleness reduction and increased flexibility and toughness), antimicrobial materials (for increasing the product's shelf-life), flavor, and color agents (for increased sensory properties and overall acceptability) can be used in the production of films [16, 71].

Novel technologies such as microwave, high hydrostatic pressure, irradiation, cold plasma, ultrasound, and highpressure homogenization are applied with the purpose of quality improvement, thermal treatment, energy efficiency, preservation, texture and surface modification, analysis, and extraction to name a few $[66,97]$. Therefore, this review attempts to discuss and address the definition and mechanism of novel technologies, the optimum conditions for the application of these technologies on the edible packaging, and the influences of the mentioned technologies on properties of edible packaging.

\section{Novel Technologies}

Microwave, high hydrostatic pressure, irradiation, cold plasma, ultrasound, and high-pressure homogenization are considered to be the most commonly applied packaging technologies. The influences of the mentioned technologies on some of the food edible packaging properties are summarized in Fig. 1.

\section{Microwave}

Electromagnetic radiation frequencies ranging from $300 \mathrm{MHz}$ to $300 \mathrm{GHz}$ create the effect of polarization and cause microwave heating. Microwave heating has advantages over traditional heating such as reducing the processing time and maintaining the quality of food. Food materials have different dielectric properties which they store and spread when exposed to an electromagnetic field. Microwave is usually used in the food industry for pre-cooking, frozen material tempering, and drying [87].

From an industrial point of view, during film production and after spreading it over the plate, it is important to select the most appropriate method such as microwave for rapid drying. In the traditional approach, the film is dried under the air, taking about $24 \mathrm{~h} \mathrm{[40].}$

Microwave can heat the components based on the transference of mass and heat through the interaction between polar material and microwave energy [72]. Because of the electromagnetic field generated by microwave, only the surface of the component is not influenced, and due to the high penetration depth, the inside parts of the materials are sufficiently heated. Furthermore, various food components have the divergence dielectric behavior and absorb heat differently and selectively [20].

\section{Effect of Microwave on Edible Packaging}

Kaya and Kaya [40] formed films containing whey protein isolate about ( 8 and $10 \%(\mathrm{w} / \mathrm{w}))$ and dried by microwave. To do this, films were spread onto the plate and dried (20 ${ }^{\circ} \mathrm{C}, 18 \mathrm{~h}$ and $40 \mathrm{RH}$ ) and microwave condition (power 700 $\mathrm{W}, 2450 \mathrm{MHz}$, and $5 \mathrm{~min}$ ). The result indicated that transfer rate of water vapor was directly related to the temperature and increased with it (from 4 to $30^{\circ} \mathrm{C}$ ). The films dried with both methods showed no main difference in terms of water vapor permeability (WVP) and modulus of elasticity (ME). Microwave method enhanced tensile strength (TS) and

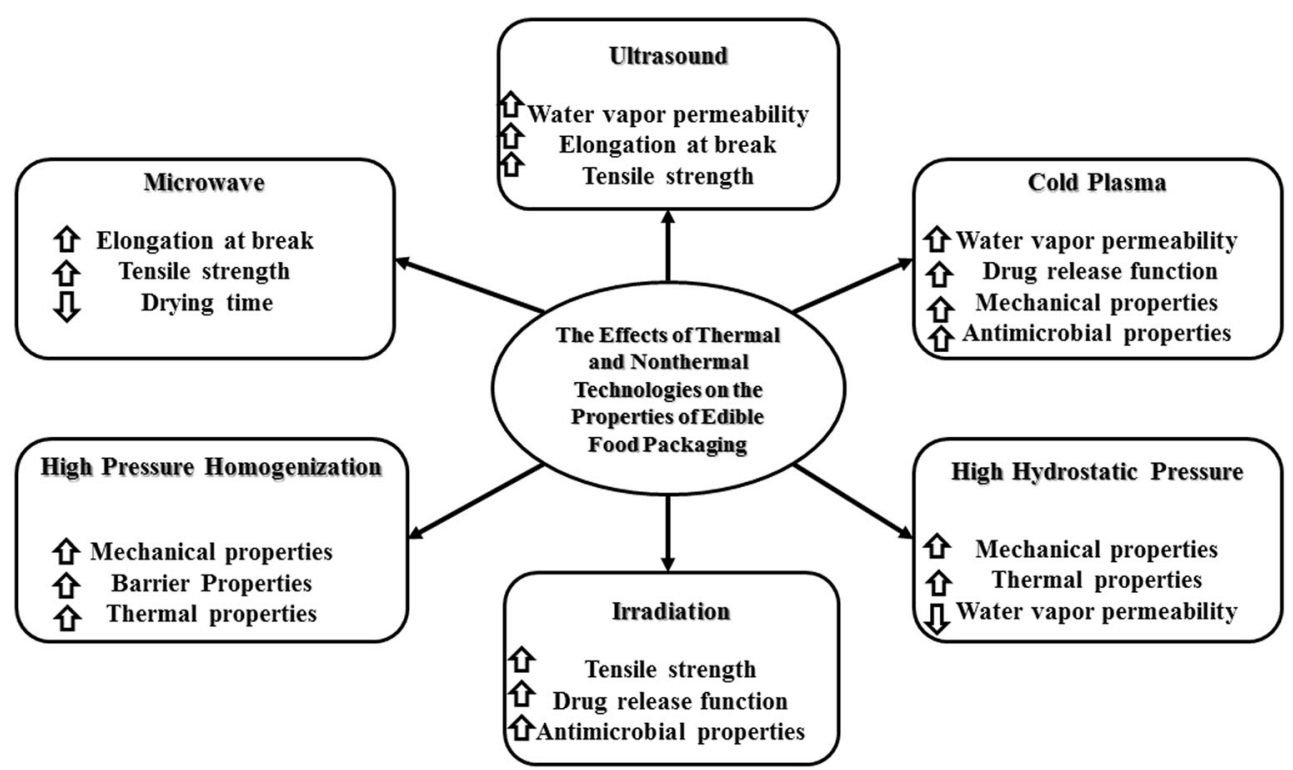

Fig. 1 The influence of technologies on the properties of edible food packaging 
elongation at break (EAB) in film samples compared to room condition. In addition, dried samples by microwave had better haze and gloss values compered to others.

Cárdenas et al. [20] dried chitosan film at convection oven $\left(12 \mathrm{~h}\right.$ at $35^{\circ} \mathrm{C}$ ) and microwave $(2450 \mathrm{MHz}, 10 \mathrm{~min})$. They dried chitosan films using two methods; microwave (full power, $10 \mathrm{~min}, 2450 \mathrm{MHz})$ and convention oven $\left(35^{\circ} \mathrm{C}\right.$ for $12 \mathrm{~h}$ ) and reported that microwave increased UV-vis light barrier property of films, although had no significant effect on their thermal and structural characteristic. In addition, Cárdenas et al. [21] reported that $\mathrm{Cu}$ nanoparticle in chitosan composite film due to connection to matrix filled binding points of film against water and accelerated the removal of non-bounded water during drying by microwave (full power, $10 \mathrm{~min}$, $2450 \mathrm{MHz}$ ). The results of studies on microwave effects on edible packaging are summarized in Table 1.

\section{Irradiation}

Food irradiation is a physical treatment used to improve the shelf-life through reducing the spoilage of various vegetables, and animal and seafoods. This process consists of exposing foods to ionizing radiation chiefly electron beam (E-beam), $\mathrm{UV}$, and $\gamma$ where high-energy radiation expels electrons from atoms and ionizes the molecules. The international unit of measurement for the radiation E-beam and the gamma dose absorbed by the product is kilogray ( $\mathrm{kGy}$ ) and UV radiation is measured in nanometers (nm) [27, 46, 47, 53]. The use of radiation technique in food products was authorized in 1981 [99].

With radiation technique, packaging with desired functional characteristics can be obtained $[4,33]$. In addition, packaging improves the physical and chemical quality of food products but does not significantly inhibit microbial growth. Irradiation is able to inhibit microbial growth and/or produce cross-linking films by covalently linking the protein molecules $[19,46,47]$.

Food protein alteration is an important approach to improving the properties of the biopolymer applied to edible film production. The irradiation process on the protein crosslinking can result in the formation of free radicals, hydrogen abstraction, and novel connection inside chains, which improves the final structure properties. Furthermore, this process occures rapidly whitout the need for catalyst and temperature rise [44].

\section{Effect of Irradiation on Edible Packaging}

E-beam irradiation (40-60 kGy) was investigated on the quercetin release level of film including gelatin and chitosan in hydroethanolic medium (30\% ethanol) at room temperature. The induced irradiation created novel interactions and connections between chitosan and gelatin with the antioxidant material, resulting in the increased quercetin level residual within the film following $60 \mathrm{kGy}$ irradiation dose. However, the lag-time (the period needed previously the release begins) increased ten times. Therefore, the E-beam irradiation led to the entrapment of a significant amount of antioxidants [12]. Irradiation by new interactions between biopolymers has been used for packaging disinfection. Gamma irradiation (32 kGy) was used to generate cross-linked proteins and prepare proteins/glycerol and protein/glycerol/polysaccharide films. Structure analysis was performed by FTIR [93]. The second derivative FTIR spectrum showed an increase in the amount of $\beta$-sheet phase and a reduction in a-helix phase in $\gamma$ irradiated cross-linked proteins in comparison with no irradiation sample. Methylcellulose addition and $\gamma$-irradiation of proteins enhanced the puncture strength and had no significant effects on WVP. Irradiation induced $40 \%$ decay in the proteins/methylcellulose/peppermint formulation on day 8 while the control underwent $65 \%$ decay. Irradiation $(\gamma)$ improves film characteristics through producing cross-connected protein.

The changes in structural parameters and the release levels of ferulic acid and tyrosol in film including gelatin and chitosan irradiated with E-beam at $60 \mathrm{kGy}$ doses were studied. Ferulic acid can cause some connections with the polymer networks; non-irradiated films showed higher remaining ferulic acid compared with tyrosol. E-beam induced a loss of about $20 \%$ in tyrosol and $27 \%$ in ferulic acid residual trapped within the matrix of polymer while all tyrosol was released. Moreover, the TS value significantly increased and water vapor permeability decreased [11]. Through some covalent bindings with the polymer network, irradiation can reduce the additive diffusivity from packaging to outside.

The chitosan coating with ultraviolet ray were applied for the preservation of jujube during storage. UV irradiation restrained the rate of respiration, electrolyte leakage, and malonaldehyde level. In addition, combined treatment for 15 days displayed $49.5 \%$ weight loss lower compared to that in the untreated and uncoated type. In addition, the enzyme avtivities of treated jujubes were kept at a higher level, and the reduction in chlorophyll and vitamin $\mathrm{C}$ was controlled [100]. After absorbing the ultraviolet, the microorganism died due to the alteration of the molecular structure of the nucleoprotein and inhibition of metabolism.

Gamma irradiation (3 kGy) process was applied together with cinnamaldehyde and thyme oil in whey and soy protein coatings for shrimp. Changes in aerobic plate counts, bacterial growth, and sensory characteristics were investigated by Ouattara et al. [66]. The obtained results revealed that coating and $\gamma$-irradiation treatments had synergistic effects on the reduction in aerobic bacteria including Pseudomonas putida and aerobic plate counts (APCs). Without irradiation, an improvement of preventive influences was observed in the coating containing antimicrobial agents applied to the shrimp related 
Table 1 The effects of microwave on edible packaging properties

\begin{tabular}{llll}
\hline Matrix & Experimental conditions & Findings & References \\
\hline Whey protein isolate & Microwave: $700 \mathrm{~W}, 245 \mathrm{MHz}$, and $5 \mathrm{~min}$ & $\begin{array}{c}\text { Microwave enhanced EAB and TS } \\
\text { and showed no effect on WVP and ME. } \\
\text { Microwave increased UV-vis light barrier } \\
\text { and had no effect on thermal properties. }\end{array}$ \\
\hline
\end{tabular}

to the level of antimicrobial materials; with irradiation, on the other hand, the preventive influence was enhanced owing to the antimicrobial material interaction influence. Irradiation had no detrimental influences on the organoleptic parameters. Irradiation with coating showed synergistic influence in initial solution without additives. In another research, gamma irradiation (1-3 kGy) decreased the APCs in three groups of beef samples containing 0 and $0.5 \%$ of ascorbic acid and a sample including ascorbic acid $(0.5 \%)$ and packed with calcium caseinate coating. Also, in all samples, thiobarbituric acid reactive substances (TBARS) and $-\mathrm{SH}$ radical production were stabilized during storage in comparison with the control sample [67]. Gamma irradiation improved lipid oxidation and $\mathrm{SH}$ radicals resulted in reduced bacterial growth.

Several food products coated with different solutions were treated with gamma ray up to $3 \mathrm{kGy}$. Irradiation combined with a coating completely inhibited the microbial growth in shrimp, decreased 2-3.5 log unit in the APCs of ready-to-eat pizzas, and significantly decreased the mold growth of strawberries. Contrary to uncoated/untreated sample, the shelf-life improved in shrimp and pizza. Gamma irradiation had no significant influence on the organoleptic parameters [68].

Edible coatings containing biodegradable materials combined with $\gamma$-irradiation prevent the microbial attack on the Hyani date fruits (considered to have high moisture content). This goal was achieved by preparing triple blend solutions (polyvinyl alcohol, chitosan, and tannic acids) using $\gamma$ irradiation with doses varying between 5 and $20 \mathrm{kGy}$. The results showed that with the increase in the irritation dose, antimicrobial properties and the TS of edible coatings were improved. Moreover, $\gamma$-irradiation with titanic acid was able to increase the shelf-life of fruit in condition $\left(12{ }^{\circ} \mathrm{C}\right.$ and $98 \%$ $\mathrm{RH})$ from 7 to 30 days [28].

Methylcellulose coating combined with citrus extract (CE), lactic acid bacteria metabolites (LAB), rosemary extract (RE), and organic acids (OA) was studied on the sensitivity of Salmonella typhimurium, Escherichia coli, and Listeria monocytogenes in broccoli florets. For this propose, florets were separately inoculated with each pathogen microorganism and packed with the coating and dipped in baths containing antimicrobial agents. Samples were irradiated with $\gamma$ irradiation at doses of 0 to $3.3 \mathrm{kGy}$. Following $\gamma$-irradiation, methylcellulose coating increased the radio sensitivity of food pathogens. The $\mathrm{OA}+\mathrm{CE}, \mathrm{OA}+\mathrm{LAB}$, and all irradiated coatings significantly reduced $E$. coli, S. typhimurium, and L. monocytogenes, respectively [86].

In a study by Abad et al. [1], the tamarillo fruits were irradiated at doses of 250 to 1000 Gy and packed with the StaFresh $2505^{\mathrm{TM}}$ coating (the yellowish wax covering palm leaves with a thick layer and applied in coating fresh fruit). The irradiated and coated fruits were preserved under better conditions compared with the control samples. Weight loss and respiration of the fruits were 48 and $30 \%$ lower than the control during its shelf life. Firmness and appearance increased up to 70 and $40 \%$ compared to the control, respectively. Furthermore, radiation had no influence on fruit flavor. The results of the studies on irradiation effects on edible packaging are summarized in Table 2.

\section{Cold Plasma}

Recently, plasma technology has been employed as an alternative to other physical and chemical methods for food processing with high quality [31, 34]. Plasma is produced by applying energy to a gas blend, and it is as the fourth state of matter which is electrified gas along with ultraviolet photons, electrons, positive and negative ions, free radicals, atoms, and excited or non-excited gas molecules. These chemically reactive particles have a significant impact on food processing. Generally, there are two types of plasma, namely thermal and nonthermal (cold plasma). The thermal plasma is produced at extreme pressures $(\geq 105 \mathrm{~Pa})$ and requires up to $50 \mathrm{MW}$ of power; also, the temperature of the electrons and ions of the plasma approach thermal equilibrium. Cold plasma, on the other hand, is generated by electrical discharge instead of heating the entire gas at atmospheric pressure and low levels of power [76, 80].

Cold plasma can be applied in the decontamination of food material with inactive microbial agents such as bacteria, bacterial spores, fungi, and viruses. Therefore, cold plasma treatment can be used as an alternative heat-based technique for sterilizing sensitive materials such as vitamins, proteins, volatile compounds, and polycarbonate and polythene [15, 62, 69]. The cold plasma has been reported to interact with ingredients of edible films such as proteins, lipids, carbohydrates (seed-mucilage), water, and phenolic compounds, through the addition or removal of the specific functional group. These interactions resulted in the uniformity of treatment, no use of 
hazardous solvents, increased mechanical strength and flexibility, and improved hydrophobic properties; they also helped maintain the sealing properties of polymers, reduce gas permeation and undesirable contaminants without any traces, maintain atmospheric air, and increase elongation $[6,8,9$, $26,60]$.

\section{Effect of Cold Plasma on Edible Packaging}

Chen et al. [23] produced film containing chitosan/ciprofloxacin/zein by plasma at $P=100 \mathrm{~W}$ for $30 \mathrm{~s}$. The result of FTIR showed that films were well coated with zein, and XRD patterns confirmed that the cold plasma had no influence on crystal type. No significant changes were observed in thickness and encapsulation efficiency while surface free energy, thermal stability, and wet ability and bacterial growth were increased and reduced, respectively. Cold plasma improved the function of drug release in film.

Cold plasma was done on carboxymethyl cellulose (CMC)-coated polypropylene film including essential oils. First, polypropylene films were modified with cold plasma at $V=14 \mathrm{kV}$ and $f=20 \mathrm{kHz}$ for $2 \mathrm{~min}$. CMC films including essential oils were then coated with plasma-treated polypropylene. The results showed that atmospheric cold plasma treatment was able to create $\mathrm{C}=\mathrm{O}$ and $\mathrm{O}-\mathrm{H}$ groups on the polypropylene films. Subsequently, contact angle, indicative of surface wettability, was reduced from $88.92^{\circ}$ to $52.12^{\circ}$.
Cold plasma increased the mechanical and antimicrobial characteristics. In addition, plasma increased WVP while essential oil decreased it [36]. In general, plasma can be used as a pretreatment in the production of bilayer film because it makes better connection of natural film to synthetic polymers.

The effect of plasma on melon packed in polypropylene film was investigated [88]. Polypropylene film was subjected to cold plasma at $15 \mathrm{kV}, 12.5 \mathrm{kHz}, \mathrm{RH}=90 \%$ for 15 to $30 \mathrm{~min}$ for each side. The findings showed that dry matter and titratable acidity increased, although insoluble solid content was reduced. Furthermore, microbial shelf life significantly increased in 15-min treatment while the effect of cold plasma on microbial shelf life after $30+30$ min was negligible. In general, cold plasma is an efficient method in the decontamination of fresh-cut-fruit.

Sifuentes-Nieves et al. [81] reported that hexamethyldisiloxane (HMDSO) cold plasma treatment $(P=$ $70 \mathrm{~W}, \mathrm{ET}=30 \mathrm{~min}$ ) enhanced hydrophobic characteristics in starch film and increased TS and Young's modulus. However, a reduction from 36 to $9 \%$ was observed in $\mathrm{EAB}$ value. These results suggested that the HMDSO plasma treatment is capable of producing starch-based films as a suitable packaging material.

Cold plasma $(P=400 \mathrm{~W}, \mathrm{ET}=15 \mathrm{~min})$ was applied on defatted soybean meal film [65]. The films were treated with different types of plasma-forming gases including Ar, dry air, $\mathrm{O}_{2}, \mathrm{He}$, and $\mathrm{N}_{2}$. No significant changes were observed in elastic modulus, TS and WVP. Lightness value and stretch

Table 2 The effects of irradiation on edible packaging properties

\begin{tabular}{|c|c|c|c|c|c|}
\hline $\begin{array}{l}\text { Type of } \\
\text { irradiation }\end{array}$ & Matrix & Type of food & $\begin{array}{l}\text { Experimental } \\
\text { conditions }\end{array}$ & Findings & Reference \\
\hline $\begin{array}{l}\text { E-beam } \\
\text { irradiation }\end{array}$ & Fish gelatin films & - & $\begin{array}{l}40 \text { and } 60 \\
\text { kGy }\end{array}$ & $\begin{array}{l}\text { The irradiation decreased the } \\
\text { release rate of quercetin }\end{array}$ & {$[12]$} \\
\hline$\gamma$-Irradiation & $\begin{array}{l}\text { Calcium caseinate-based } \\
\text { coating }\end{array}$ & Ground beef & $\begin{array}{l}0,1,2 \text {, and } 3 \\
\mathrm{kGy}\end{array}$ & $\begin{array}{l}\text { Irradiation significantly decreased APCs and } \\
\text { stabilized TBARS and free SH }\end{array}$ & {$[67]$} \\
\hline UV-irradiation & Chitosan coating & Jujube & $253.7 \mathrm{~nm}$ & $\begin{array}{l}\text { UV-irradiation controlled the rate } \\
\text { of respiration and weight loss of fruit. }\end{array}$ & {$[100]$} \\
\hline$\gamma$-Irradiation & $\begin{array}{l}\text { Soy protein or whey } \\
\text { protein isolate }\end{array}$ & Pre-cooked shrimp & 3 kGy & $\begin{array}{l}\text { Gamma irradiation inhibited the } \\
\text { growth of aerobic bacteria }\end{array}$ & {$[66]$} \\
\hline $\begin{array}{l}\text { E-beam } \\
\text { irradiation }\end{array}$ & Chitosan-gelatin films & $\begin{array}{l}\text { Antioxidants (ferulic } \\
\text { acid and tyrosol) }\end{array}$ & 60 kGy & $\begin{array}{l}\text { E-beam decreased the release rate } \\
\text { of acid and tyrosol, and increased TS }\end{array}$ & {$[11]$} \\
\hline$\gamma$-Irradiation & $\begin{array}{l}\text { Soy and whey protein } \\
\text { isolates coating }\end{array}$ & $\begin{array}{l}\text { Pre-cooked shrimps, } \\
\text { pizzas, and } \\
\text { strawberries }\end{array}$ & 0 and $3 \mathrm{kGy}$ & $\begin{array}{l}\text { Irradiation had effect on microbial growth } \\
\text { and no effect on sensory characteristics }\end{array}$ & {$[68]$} \\
\hline$\gamma$-Irradiation & $\begin{array}{l}\text { Calcium caseinate, and } \\
\text { whey protein isolate } \\
\text { film }\end{array}$ & Strawberries & 32 kGy & $\begin{array}{l}\text { Gamma irradiation of proteins increased } \\
\text { the puncture strength }\end{array}$ & {$[93]$} \\
\hline$\gamma$-Irradiation & $\begin{array}{l}\text { Polyvinyl } \\
\text { alcohol/chitosan/tannic } \\
\text { acid }\end{array}$ & Hayani date fruit & 5 to $20 \mathrm{kGy}$ & $\begin{array}{l}\text { Irradiation enhanced the mechanical } \\
\text { properties of fruit }\end{array}$ & {$[28]$} \\
\hline$\gamma$-Irradiation & Methylcellulose coating & Broccoli florets & $0-3.3 \mathrm{kGy}$ & $\begin{array}{l}\text { Gamma irradiation eliminated the growth } \\
\text { of foodborne pathogens }\end{array}$ & {$[86]$} \\
\hline$\gamma$-Irradiation & StaFresh $2505^{\mathrm{MT}}$ coating & Tamarillo fruits & $0.25-1 \mathrm{kGy}$ & $\begin{array}{l}\text { Irradiation reduced weight loss up to } 48 \% \text { and } \\
\text { respiration rate and increased firmness, and } \\
\text { appearance }\end{array}$ & {$[1]$} \\
\hline
\end{tabular}


ability increased in the case of all gases except for air, $\mathrm{N}_{2}$ and Ar. The effect of cold plasma on smoked salmon packed with DSM film was further investigated. Cold plasma indicated no influence on the color of salmon while it delayed lipid oxidation and reduced the hardness [65].

Pankaj et al. [70] treated sodium caseinate film by plasma ( $V=60$ and $70 \mathrm{kV}$, ET $=1-5 \mathrm{~min}$ ). Plasma was able to enhance hydrophilic property in films owing to the enhance in $\mathrm{O}-\mathrm{H}$ and $\mathrm{C}=\mathrm{O}$ groups. In addition, roughness and surface oxygen content and glass transition temperature increased and decreased, respectively. The effect of cold plasma on film and coating are summarized in Table 3.

\section{Ultrasound}

Edible films have weak mechanical properties in comparison with synthetic samples. Therefore, various physical and chemical technologies need to be done to overcome these problems. Ultrasound had beneficial effects on the processing and preservation of food. The ultrasound technology is divided into low and high intensities. In low-intensity technology, high frequency $(2-20 \mathrm{MHz})$ and low power $\left(100 \mathrm{~mW} / \mathrm{cm}^{2}\right.$ to $<1 /$ $\mathrm{w}^{2}$ ) are used. This type as an analytical method examines information about quality properties of food [59]. But in high-intensity ultrasound, typically low frequencies range $(20-100 \mathrm{kHz})$ and high power range $\left(10-1000 \mathrm{~W} / \mathrm{cm}^{2}\right)$ are used. This method had several application in food systems inducing filtration, fogging, crystallization, emulsification, cutting, degassing, oxidation and reduction reactions, drying, extraction, tenderization, cleaning, and sterilization $[58,59]$. High-intensity type transmitted via a fluid environment create strings or cloudy bubbles. The bubble grows at critical sizes and will quickly disappear. The general process is called cavitation phenomenon, which involves the creation, growth, and breakdown of bubbles. The growth and breakdown of bubbles will result in the production of high temperatures and pressures in the matrix [5]. In addition, ultrasound can be used for increasing the mass transfer owing to the great temperature and pressure changes. The combination of microwave and ultrasound can accelerate the extraction technique for target materials from their matrix $[48,52]$.

\section{Effect of Ultrasound on Edible Packaging}

Ahmadi et al. [2] studied ultrasound treatment ( $35 \mathrm{kHz}$ ) for 5, 15,30 , and $45 \mathrm{~min}$ on methylcellulose-forming solutions. The time of ultrasound exposure had an inverse relationship with the amount of WVP, meaning an ultrasound process of $45 \mathrm{~min}$ produced the lowest WVP. The highest EAB and TS were obtained at 45 and $5 \mathrm{~min}$, respectively. Following $5 \mathrm{~min}$ of ultrasound, mechanical properties were improved, although with the increase in time to $30 \mathrm{~min}$, TS and EAB values of films were reduced. These results can be ascribed to the cavitation phenomenon. The reduction in TS and EAB after 30 min can be the result of the increased cavitation size and number of bubbles. Growing bubbles create spaces between molecules and reduce film resistance. Increases in these parameters after $45 \mathrm{~min}$ of sonication can be due to the breakdown in chemical connections in the main chain of methylcellulose films and the formation of new chemical bonds, forming a denser network. Under the influence of high pressure and temperature due to solvent decomposition and dissolved molecules inside the system of bubbles, several reactive radicals are produced. According to the cavitation mechanism, the contact between the methylcellulose film solution and ultrasonic waves can cause the dissolved water and ethanol molecules to collapse, thereby creating hydrogen and hydroxyl radicals. Ultrasound can decrease WVP because of the creation of covalent connection between steam and water molecules and radicals. This reaction can possibly reduce WVP through trapping the water molecules inside the network. Furthermore, increasing the time of exposure with ultrasound waves can increase the number of radicals and covalent bonds and decrease WVP, respectively.

Fan et al. [30] used ultrasonic pretreatment (19 W, $5 \mathrm{~min}$ at room temperature) to modulate the interaction between the kidney bean protein isolate (KBPI) and chitosan and prepare composite films. The ultrasonic increased blending between KBPI and chitosan generated flexible films. Moreover, ultrasound pretreatment had no effect on the transmission of light, thereby increasing the opacity of the film.

Borah et al. [14] applied ultrasound treatment $(40 \pm 3 \mathrm{kHz}$, $50 \mathrm{~W}, T=45$, and $60 \mathrm{~min}$ ) to composite film forming solutions of lime pomace and potato peel powder. Ultrasound treatment improved film properties with the increase in sonicated duration time, and decreased WVP and film moisture absorption in sample via 60-min sonication. In addition, ultrasound treatment increased the stretching properties of the composite films.

Sun et al. [84] confirmed that ultrasound treatment (up to $20 \mathrm{~s}, 24 \mathrm{kHz}$ ) is an appropriate method for solutions of soy protein films and positively affects the number and dispersion of soybean protein seeds. The size of the seeds decreased with the increase in the time of ultrasound exposure, resulting in a uniform appearance of the film. Also, the soy protein film structure of the ultrasound treatment was more uniform and its mechanical properties significantly improved, which ultimately caused a significant difference in TS and EAB.

Marcet Manrique et al. [56] applied ultrasound (20 kHz at several temperatures and times) in the egg yolk film-forming solution. Optimum ultrasound treatment was $45^{\circ} \mathrm{C}$ for $40 \mathrm{~min}$ for film preparation. Optimum conditions for ultrasound treatments improved the resolution of casting solutions, solubility, thickness, and mechanical characteristics of the prepared films. The results (lower particle size, lower poly dispersity index, and more film compression) showed that ultrasound 
Table 3 The effects of cold plasma on edible packaging properties

\begin{tabular}{|c|c|c|c|c|}
\hline Matrix & Type of food & Experimental conditions & Findings & References \\
\hline $\begin{array}{l}\text { Polypropylene } \\
\text { film }\end{array}$ & Fresh-cut-melon & $\begin{array}{c}V=15 \mathrm{kV}, f=12.5 \mathrm{kHz}, \mathrm{RH}= \\
90 \%, \mathrm{ET}=15, \text { and } 30 \mathrm{~min}\end{array}$ & $\begin{array}{l}\text { Increased dry matter, titratable acidity and shelf-life and de- } \\
\text { creased soluble solid content. }\end{array}$ & [88] \\
\hline $\begin{array}{l}\text { Chitosan-based } \\
\text { film }\end{array}$ & - & $\begin{array}{l}P=100 \mathrm{~W}(65 \mathrm{~V}, 1.5 \mathrm{~A}), d=5 \\
\quad \mathrm{~mm}, \mathrm{ET}=30 \mathrm{~s}\end{array}$ & $\begin{array}{l}\text { Increased surface free energy, thermal stability, WVP, and drug } \\
\text { release function and reduced bacterial growth. }\end{array}$ & [23] \\
\hline Starch-based film & - & $P=70 \mathrm{w}, \mathrm{ET}=30 \mathrm{~min}$ & $\begin{array}{l}\text { Increased WVP, TS, Young's modulus, and hydrophobic } \\
\text { property and decreased EAB. }\end{array}$ & [81] \\
\hline $\begin{array}{l}\text { Defatted soybean } \\
\text { meal film }\end{array}$ & Smoked salmon & $P=400 \mathrm{~W}, \mathrm{ET}=15 \mathrm{~min}$ & $\begin{array}{l}\text { Increased stretch ability and lightness and decreased lipid } \\
\text { oxidation and hardness. }\end{array}$ & {$[65]$} \\
\hline $\begin{array}{l}\text { (CMC)-coated } \\
\text { polypropylene } \\
\text { film }\end{array}$ & - & $\begin{array}{l}V=14 \mathrm{kV}, f=20 \mathrm{kHz}, \mathrm{ET}=2 \\
\min \end{array}$ & Increased WVP, antimicrobial and mechanical properties. & [36] \\
\hline $\begin{array}{l}\text { Sodium caseinate } \\
\text { film }\end{array}$ & - & $V=60$ and $70 \mathrm{kV}, \mathrm{ET}=1-5 \mathrm{~min}$ & $\begin{array}{l}\text { Increased the roughness, surface oxygen content, and hydrophilic } \\
\text { property and decreased glass transition temperature. }\end{array}$ & [70] \\
\hline
\end{tabular}

was able to degrade protein aggregation by modifying the protein structure from the breaking point of covalent and non-covalent bonds.

Liu et al. [51] applied ultrasound treatment for 0, 10, 20, 30 , and $40 \mathrm{~min}$ at $40 \mathrm{kHz}$ frequency and $50 \mathrm{~W}$ to produce composite film solutions using tea polyphenol/polyvinyl alcohol by stripping method. Ultrasound treatment decreased the TS. The best overall film properties were achieved at 2:8 volume ratio of tea polyphenol/polyvinyl alcohol and 30-min ultrasound duration.

Zhong et al. [101] determined the effects of different ultrasound treatments $\left(20^{\circ} \mathrm{C}, 0-30 \mathrm{~min}, 25 \mathrm{kHz}\right.$, and $0,90,180$, and $270 \mathrm{~W}$ ) on the blending film of methylcellulose/stearic acid. Exacerbation of the treatment condition, including ultrasound exposure time, resulted in reduced viscosity of the methylcellulose/stearic acid composite emulsions and increased the homogenization of fat distribution and internal microstructure of films. Ultrasound treatment improved mechanical and superficial hydrophobic properties. The treated sample showed the lowest WVP for $10 \mathrm{~min}$ and $270 \mathrm{~W}$. However, excessive exposure to ultrasound reduced mechanical properties and moisture inhibition and created enormous spaces in the polymer matrix, leading to a negative effect on film performance. Furthermore, ultrasound improved the hydrophobic surface characteristics of composite films in the appropriate range. In general, ultrasound, as a modification form of film-forming emulsions, significantly enhances the compositional properties of films.

Cheng et al. [24] made use of sonication $(20 \mathrm{kHz}$ for $0,2.5$, $5,10,15$, and $30 \mathrm{~min}$ at $60 \pm 3{ }^{\circ} \mathrm{C}$ ) to measure the dispersions of gelatinized maize starch film-forming solutions. Ultrasound treatment improved transparency, moisture resistance, and film structure. Furthermore, this treatment enhanced the starch amylose solubility and the free mobility of polymers in starch dispersion, resulting in a sharp reduction in viscosity and increased solubility even for $10 \%$ dispersion.
Marcuzzo et al. [57] applied ultrasound treatment at $24 \mathrm{~Hz}$ for (3-12) min on gluten-based film-forming solutions because protein films obtained from gluten in acidic conditions exhibited some of the problems in protein dispersion. Sonication process is considered as a physical method for improving protein dispersion and the appearance of this film without adding a chemical additive. Gluten had a high tolerance to ultrasound treatment, a useful approach to improving the hydrophilic surface properties and appearance of films.

Rodriguez-Turienzo et al. [73] applied sonication $(820 \mathrm{~W}$, $35 \mathrm{kHz}$ for 1,15 , and $60 \mathrm{~min}$ ) on the whey protein coatingforming solutions for frozen salmon fish. The results showed a reduction in drip loss in thawing and after cold storage in coated fish treated for $60 \mathrm{~min}$ than those sonicated for 15 min. The ultrasound treatment had no effect on the color of frozen fish, but enhanced the whiteness of the salmons during cooking compared to samples coated with un-sonicated whey protein. These coatings had no influence on sensory characteristics of fish. Ultrasound treatment significantly inhibited the lipid oxidation of salmon fillet compared to uncoated and un-sonicated samples. Therefore, ultrasound treatment of whey protein solutions can reduce the oxidation of frozen fish fats without adding chemicals and enhanced the shelf-life of products.

Banerjee et al. [7] used sonication (acoustic power, $168 \mathrm{kHz}$ and $520 \mathrm{kHz}$ for 0.5 and $1 \mathrm{~h}$ ) to produce sodium caseinate and whey protein concentrate (WPC) films. Sonication process enhanced the TS of films. The average of TS in treated film was $224 \%$ compared to the untreated film. The ultrasound process in sodium caseinate films was more effective compared with WPC film. The intermediate power with low-frequency levels led to a much better TS in sodium caseinate film. Increasing the time of ultrasound exposure resulted in more powerful films.

Wang et al. [96] produced modified microcrystalline wheat bran cellulose (MWBC) by acid hydrolysis of wheat-bran 
cellulose (WBC) using microwave/ultrasonic system $(300 \mathrm{~W}$, $30{ }^{\circ} \mathrm{C}$, and $15 \mathrm{~min}$ ). Then they formed a film of it. The result indicated that ultrasonic/microwave system enhanced tensile strength (TS) and water holding capacity (WHC) and reduced oxygen permeability (OP) and water vapor permeability (WVP) contents in films containing MMWBC due to decreasing of particle size and increasing of free hydroxyl numbers and interactions of carboxyls with amino components. In general, this system varied mechanical characteristics due to effect on size, packing style, distribution, and shape of filler particles. Also, ultrasonic/microwave system improved thermal properties such as $\mathrm{Tg}$ and $\mathrm{Tc}$ due to breaking of hydrogen links and happening of acid hydrolysis in wheat-bran cellulose amorphous part that maintain stable of crystalline part.

Wang et al. [97] determined the effect of microwave/ ultrasonic system $\left(20^{\circ} \mathrm{C}, 500 \mathrm{~W}, 0,10,20,30\right.$, and $\left.40 \mathrm{~min}\right)$ on film containing soy protein and titanium dioxide. With the increase of microwave/ultrasonic system time up to $20 \mathrm{~min}$ increased TS, homogenous of structure and WHC and reduced WVP and OP. This system produced films with compact and homogeneous surfaces due to reducing of particle size, increasing of particle surface, free hydroxyls, and interaction of particles together, although longer time of treatment, could destroy matrix and produce a weak film.

Wang et al. [98] determined the effects of ultrasound/ microwave treatment $\left(20{ }^{\circ} \mathrm{C}\right.$ to avoid of oleic acid oxidation, $15 \mathrm{~min}$ and $500 \mathrm{~W}$ ) on soybean protein isolate (SPI) edible films with different proportions from oleic acid to stearic acid. In summary, variations in stearic acid and oleic acid ratios and microwave/ultrasound treatment had important impact on WVP and angular contact angle. Film containing $3: 2$ ratio of stearic acid to oleic acid prepared under microwave/ultrasound condition $\left(20^{\circ} \mathrm{C}\right.$, $15 \mathrm{~min}$, and $500 \mathrm{~W}$ ) indicated the lowest WVP and the highest angle $\left(135^{\circ}\right)$. The lower temperature and period of microwave may rely on activating and facilitating the influence of radiation on the solid phase emission [79]. However, the effect of ultrasound causes cavitation (creation, growth and breakdown of bubbles) in the solution [25]. Consequently, ultrasound/microwave process $(15 \mathrm{~min}$ and $500 \mathrm{~W})$ resulted in the creation of compressed-films, followed by improved contact angles. Also, the surface of treated films is fairly uniform because ultrasound/ microwave treatment improves the mixing of films, resulting in a relatively smooth and continuous surface [96]. The results pertaining to studies on ultrasound and ultrasound/microwave effects on edible packaging are summarized in Table 4 .

\section{High-Pressure Homogenization}

High-pressure homogenization (HPH) develops the structural and physicochemical characteristics of packaging thus it can be applied in film production $[32,37,74,82]$. HPH treatment has been employed in the food industry to process various food products, including meat, fruits, juices, and vegetables with a pressure range of 100 to $800 \mathrm{MPa}$ depending on the application purpose [3]. The influence of HPH process depends on the applied pressure, temperature, storage time, and molecular size [64]. Several studies have reported that the HPH process reduces the internal viscosity, increases the power of inflation [54], forms a weak gel [95], decreases temperature and enthalpy gelatinization [38], and affects the crystalline structure $[22,94]$.

\section{Effect of HPH on Edible Packaging}

Saricaoglu et al. [75] used HPH treatment at a pressure between 0 and $150 \mathrm{MPa}$ on meat protein solution for film forming. By enhancing pressure to $100 \mathrm{MPa}$ in suspensions treated, the particle size decreased and then increased due to protein accumulation. The reduction in particle size decreased water solubility and increased WVP and TS. The reduction in the size of the particle protein resulting from the increase in the pressure up to $100 \mathrm{Mpa}$ led to the homogeneous distribution of their particles. All samples were homogeneous except the sample homogenized with $150 \mathrm{MPa}$. The non-porous and smooth film resulted in a higher film clarity. Additionally, the $\mathrm{EAB}$ values increased by the increase in pressure to 100 $\mathrm{MPa}$, but reduced with a pressure to $150 \mathrm{MPa}$. In general, $\mathrm{HPH}$ treatments to $100 \mathrm{MPa}$ improved the solution characteristics and the preventive and mechanical properties of film.

Shahbazi et al. [77] evaluated starch under the influence of $\mathrm{HPH}$ at 14 and $20 \mathrm{MPa}$ for production of film including starch and $\mathrm{k}$-carrageenan. It can be concluded that this method is safe for starch, inexpensive, and fast. In addition, the HPH process produced smooth hydrogels with stronger gel nets, and reduced the degree of crystallization in starch grains and the amount of crystallization relative. The HPH process resulted in a better dispersion of starch in the k-carrageenan matrix, which ultimately increased water resistance and film obstruction properties. The produced film under HPH had the highest hydrophobic level and TS value. These changes were more pronounced when applied with a high level of homogenization pressure. HPH had no influence on starch granules integrity. However, the many points and cavities appearing outside the granule were increased with the increase in process intensity. In addition, the pressure produced during HPH can cause physical damage to the starch granule. The probable changes in the shape and appearance of granules were due to the partial gelatinization caused by the increase in the temperature during homogenization [94]. Changes and cavities created at the cross section of wheat starch were due to the high pressure and shear of sonication, but the integrity of granules did not change [55]. 
Table 4 The effects of ultrasound and ultrasound/microwave on edible packaging properties

\begin{tabular}{|c|c|c|c|}
\hline Matrix & Experimental Conditions & Main findings & Reference \\
\hline Methylcellulose film & $\begin{array}{l}\text { Frequency }(35 \mathrm{kHz}) \text { for times }(5,15,30, \\
\quad \text { and } 45 \mathrm{~min})\end{array}$ & WVP, TS and EAB increased. & {$[2]$} \\
\hline $\begin{array}{l}\text { Chitosan/bean protein } \\
\text { isolate film }\end{array}$ & $\begin{array}{l}\text { Power ( } 19 \mathrm{~W}) \text { for } 5 \mathrm{~min} \text { at room } \\
\text { temperature }\end{array}$ & The opacity of the film increased and produced flexible film. & {$[30]$} \\
\hline $\begin{array}{l}\text { Potato peel/lime pomace } \\
\text { film }\end{array}$ & $\begin{array}{l}\text { Frequency }(40 \pm 3 \mathrm{kHz}) \text {, power }(50 \mathrm{~W}) \text {, for } \\
45 \text { and } 60 \mathrm{~min}\end{array}$ & Film properties improved with increasing ultrasound time. & {$[14]$} \\
\hline Soy proteins film & Frequency $(24 \mathrm{kHz})$ for $0-20 \mathrm{~s}$ & Uniformity and mechanical properties (TS and EAB) improved. & {$[84]$} \\
\hline Egg yolk film & $\begin{array}{l}\text { Frequency }(20 \mathrm{kHz}) \text { at several } \\
\text { temperatures and times }\end{array}$ & $\begin{array}{l}\text { The resolution of solutions, mechanical properties, thickness and } \\
\text { solubility of film improved. }\end{array}$ & {$[56]$} \\
\hline $\begin{array}{l}\text { Tea polyphenol/polyvinyl } \\
\text { alcohol based film }\end{array}$ & $\begin{array}{l}\text { Power }(50 \mathrm{~W}) \text {, Frequency }(40 \mathrm{kHz}) \text { for } 0 \text {, } \\
10,20,30 \text {, and } 40 \mathrm{~min}\end{array}$ & TS reduced. & {$[51]$} \\
\hline $\begin{array}{l}\text { Methylcellulose/stearic } \\
\text { acid blending film }\end{array}$ & $\begin{array}{l}\text { Power }(0,90,180 \text {, and } 270 \mathrm{~W}) \text {, frequency } \\
(25 \mathrm{kHz}) \text { at } 20^{\circ} \mathrm{C} \text { for } 0-30 \mathrm{~min}\end{array}$ & $\begin{array}{l}\text { The viscosity reduced and increased fat distribution, internal } \\
\text { microstructure, and mechanical properties. }\end{array}$ & {$[101]$} \\
\hline $\begin{array}{l}\text { Gelatinized maize starch } \\
\text { film }\end{array}$ & $\begin{array}{l}\text { Frequency }(20 \mathrm{kHz}) \text { for }(0,2.5,5,10,15 \\
\text { and } 30 \mathrm{~min}) \text { at } 60 \pm 3^{\circ} \mathrm{C}\end{array}$ & The viscosity reduced and enhanced solubility of starch amylose. & {$[24]$} \\
\hline Gluten-based film & Frequency $(24 \mathrm{~Hz})$ for $3-12 \mathrm{~min}$ & Enhanced protein dispersion and the appearance of film. & {$[57]$} \\
\hline Whey protein film & $\begin{array}{l}\text { Power }(820 \mathrm{~W}) \text {, frequency }(35 \mathrm{kHz}) \text { for }(1 \text {, } \\
15 \text {, and } 60 \mathrm{~min})\end{array}$ & $\begin{array}{l}\text { Drip loss in thawing and lipid oxidation decreased and had no } \\
\text { change on the color of frozen fillets and sensory properties. }\end{array}$ & {$[73]$} \\
\hline $\begin{array}{l}\text { Whey protein/sodium ca- } \\
\text { seinate concentrate film }\end{array}$ & $\begin{array}{l}\text { Power (low-high), frequency ( } 168 \mathrm{kHz} \text { and } \\
520 \mathrm{kHz}) \text {, for }(0.5 \text { and } 1 \mathrm{~h})\end{array}$ & $\begin{array}{l}\text { TS increased. Sonication in sodium caseinate films showed more } \\
\text { effective than whey protein concentrate film. }\end{array}$ & [7] \\
\hline $\begin{array}{l}\text { Soy protein isolate }+ \text { WBC } \\
+ \text { MWBC film }\end{array}$ & $\begin{array}{l}\text { Microwave/ ultrasonic system: } 30{ }^{\circ} \mathrm{C} \text { and } \\
300 \mathrm{~W} \text { for } 15 \mathrm{~min}\end{array}$ & $\begin{array}{l}\text { Ultrasound/ microwave improved TS and WHC and reduced } \\
\text { WVP and OP. }\end{array}$ & [96] \\
\hline $\begin{array}{l}\text { Soy protein isolate/ } \mathrm{TiO}_{2} \\
\text { film }\end{array}$ & $\begin{array}{l}\text { Microwave/ ultrasonic system: } 20^{\circ} \mathrm{C} \\
500 \mathrm{~W} \text { for } 0,10,20,30 \text {, and } 40 \mathrm{~min}\end{array}$ & $\begin{array}{l}\text { System time up to } 20 \text { min increased TS, homogenous of structure } \\
\text { and WHC and reduced WVP and OP. }\end{array}$ & [97] \\
\hline SPI + oleic and stearic acids & $\begin{array}{l}\text { Microwave/ ultrasonic system: } 20^{\circ} \mathrm{C}, 15 \\
\text { min, and } 500 \mathrm{~W}\end{array}$ & $\begin{array}{l}\text { Ultrasound/ microwave improved the mixing of film resulted in } \\
\text { uniformity of surface. }\end{array}$ & [98] \\
\hline
\end{tabular}

Molinaro et al. [61] studied the influence of pressure combined with storage time and temperature on gelatin solution. Optimum $\mathrm{HPH}$ process was set at pressure $(600 \mathrm{MPa})$ and time $(30 \mathrm{~min})$ at $20.45{ }^{\circ} \mathrm{C}$. Shelf life increased in products pecked by films produced using this method.

The films produced in optimal conditions showed no significant influence on thermal and mechanical characteristics and water vapor transmission rate. The transmission rate value was reduced at pressures above $600 \mathrm{MPa}$. Oxygen transmission rate decreased when a high pressure was applied to a gelatin-based film solution for a long time at room temperature may be due to the presence of a dense polymer matrix affecting oxygen transmission rate that blocks the release of oxygen molecules [45].

Longer high pressure produced films with compact polymer matrix and decreased oxygen transmission rate. High-pressure treatment influenced the structure of gelatin films and prevented the creation of semi-crystalline region, hence the reduction in the crystalline phase. Heremans and Smeller [35] reported that the pressure from 500 to $600 \mathrm{MPa}$ was sufficient to make compatible variations in protein. In addition, the reduction in the enthalpy showed the amount of crystalline inside the system due to the highpressure mechanical forces. High pressure increased mechanical properties in films. The mechanical forces during high-pressure treatment increased rigidity in the gelatin gel due to the improvement of hydrogen bonding. Optimum conditions had a significant increase in water-proofing properties of film [61]. The higher density in the gelatinbased film structure reduced the rate of water vapor transmission value due to the increase in the resistance of films to the water releases [89]. Films produced under highpressure treatments were lighter, redder, and more rigorous than control films. The enhance in lightness is be due to the increase in light diffusion from denatured proteins [85]. A summary of studies on HPH effects in packaging are reported in Table 5 .

\section{High Hydrostatic Pressure}

As a nonthermal process, high hydrostatic pressure (HHP) has been applied to the structural and physical modification of biopolymers including protein and polysaccharide. The reaction balance of the system moves toward to the reduction of exterior forces under high-pressure situation; consequently, with decreasing volume, the HHP leads to chemical reaction and modifications in physical structure [50]. Additionally, HHP can prevent the loss of moisture during processing and cause physical modification in the film properties [49, 90]. 


\section{Effect of HHP on Edible Packaging}

High hydrostatic pressure (HHP) can be used for physical modification of starch. The application of this method induces a unique starch gelatinization at room condition compared to samples treated under thermal condition [18, 39, 41, 90]. Starch granules were partially decomposed by high pressure, and the gel texture became harder and had less amount of amylose release compared with samples treated by the thermal method [13, 18, 90, 92].

Kim et al. [42] gelatinized starch by HHP to produce buckwheat and tapioca starch films. Films prepared via HHP had better physical properties, water resistance, and thermal properties compared to those prepared by heat treatment process regardless of the starch type. Consequently, HHP can be applied as a cold gelatinization method in the preparation of starch films. A high degree of hydrostatic pressure processing at $600 \mathrm{MPa}\left(20^{\circ} \mathrm{C}, 20 \mathrm{~min}\right)$ and thermal processing $\left(90^{\circ} \mathrm{C}, 20\right.$ min) was used for starch gelatinization. As a result, films prepared under HHP had higher TS and EAB compared with those under thermal conditions, regardless of the starch type. Buckwheat starch films produced by HHP had lower WVP and higher water solubility in comparison with heat treatment films. Starch films prepared using HHP are able to maintain a higher moisture content in the film matrix compared to thermal processing films, and water can act as a plasticizer in starch-based films [78]. In addition, film solutions prepared using HHP have less viscosity compared to those treated by thermal conditions mainly because of the crystalline structure residue that prevents the melting of amylopectin molecules by amylose until some are stabilized [83]. HHP in starchy films results in higher formation enthalpy and improves the thermal stability of films [42]. In general, the optical properties of films prepared using HHP can be the result of various reasons such as sample type and process condition (pressure, time, and temperature).

\section{Conclusion}

Edible films and coatings are placed on/or within foods and have special functions such as mechanical protection of food, inhibition of material transfer (water, gas, fat), preservation, and transfer of food components and additives such as colors and flavors and prevention of microorganism growth. Widespread researches have been studied for novel thermal and nonthermal technologies to improve edible film and coating properties and their application in food industry. As a result, to improve the novel thermal and nonthermal effects on packaging, different parameters such as technology properties, types of edible film and coating, type of food matrix, and packaging storage condition must be considered. As a suggestion, the combination of different technology effects on edible film and coating features can be considered.

Acknowledgment This study is related to the project No. 22117 with code of ethics (IR.SBMU.RETECH.REC.1398.735) from Student Research Committee, Shahid Beheshti University of Medical Sciences, Tehran, Iran. We also appreciate the "Student Research Committee" and "Research \& Technology Chancellor" in Shahid Beheshti University of Medical Sciences for their financial support of this study.

\section{References}

1. Abad J, Valencia-Chamorro S, Castro A, Vasco C (2017) Studying the effect of combining two nonconventional treatments, gamma irradiation and the application of an edible coating, on the postharvest quality of tamarillo (Solanum betaceum Cav.) fruits. Food Control 72:319-323

2. Ahmadi E, Sareminezhad S, Azizi MH (2011) The effect of ultrasound treatment on some properties of methylcellulose films. Food Hydrocoll 25(5):1399-1401

3. Argyri A.A, Tassou C.C, Samaras F, Mallidis C, Chorianopoulos $\mathrm{N}$ (2014) Effect of high hydrostatic pressure processing on microbiological shelf-life and quality of fruits pretreated with ascorbic acid or SnC12. Biomed Res Int

4. Arvanitoyannis I, Dionisopoulou N (2010) Irradiation of edible films of plant and animal origin

5. Ashokkumar M, Sunartio D, Kentish S, Mawson R, Simons L, Vilkhu K, Versteeg CK (2008) Modification of food ingredients by ultrasound to improve functionality: a preliminary study on a model system. Innovative Food Sci Emerg Technol 9(2):155-160

Table 5 The effects of HPH on edible packaging properties

\begin{tabular}{|c|c|c|c|}
\hline Matrix & $\begin{array}{l}\text { Experimental } \\
\text { conditions }\end{array}$ & Findings & Reference \\
\hline $\begin{array}{l}\text { Deboned chicken } \\
\text { meat proteins film }\end{array}$ & $\begin{array}{l}\text { Treatment at a } \\
\text { pressure } \\
\text { between } 0 \text { and } \\
150 \mathrm{MPa}\end{array}$ & $\begin{array}{l}\text { Improvement of } \\
\text { film-forming } \\
\text { solutions and } \\
\text { mechanical } \\
\text { and barrier } \\
\text { properties of } \\
\text { film (HPH } \\
\text { about } 100 \\
\text { Mpa) }\end{array}$ & [75] \\
\hline $\begin{array}{l}\text { Buckwheat and } \\
\text { tapioca starch } \\
\text { films }\end{array}$ & $\begin{array}{l}600 \mathrm{MPa}\left(20^{\circ} \mathrm{C},\right. \\
20 \mathrm{~min}) \text { and } \\
\text { thermal } \\
\text { processing }(90 \\
\left.{ }^{\circ} \mathrm{C}, 20 \mathrm{~min}\right)\end{array}$ & $\begin{array}{l}\text { Improvement of } \\
\text { physical } \\
\text { properties, } \\
\text { water } \\
\text { resistance and } \\
\text { thermal } \\
\text { properties of } \\
\text { film }\end{array}$ & {$[42]$} \\
\hline $\begin{array}{l}\text { K-carrageenan/starch } \\
\text { blend film }\end{array}$ & $\begin{array}{l}14 \mathrm{MPa} \text { (two and } \\
\text { five passes) } \\
\text { and } 20 \mathrm{MPa} \\
\text { (two passes) }\end{array}$ & $\begin{array}{l}\text { Improvement } \\
\text { mechanical } \\
\text { properties and } \\
\text { WVP }\end{array}$ & [77] \\
\hline $\begin{array}{l}\text { Gelatin-based } \\
\text { packaging films }\end{array}$ & $\begin{array}{l}(600 \mathrm{MPa}) \text { and } \\
\text { time }(30 \mathrm{~min}) \\
\text { at } 20.45^{\circ} \mathrm{C}\end{array}$ & $\begin{array}{l}\text { Improvement of } \\
\text { water-proofing } \\
\text { properties of } \\
\text { film }\end{array}$ & {$[61]$} \\
\hline
\end{tabular}


6. Bahrami N, Bayliss D, Chope G, Penson S, Perehinec T, Fisk ID (2016) Cold plasma: a new technology to modify wheat flour functionality. Food Chem 202:247-253

7. Banerjee R, Chen H, Wu J (1996) Milk protein-based edible film mechanical strength changes due to ultrasound process. J Food Sci 61(4):824-828

8. Beikzadeh S, Peighambardoust S, Beikzadeh M, Javar-Abadi MA, Homayouni-Rad A (2016) Effect of psyllium husk on physical, nutritional, sensory and staling properties of dietary prebiotic sponge cake. Czech J Food Sci 34:534-540

9. Beikzadeh S, Peyghambardoust S, Homayouni RA, Beikzadeh M (2017) Effects of Psyllium and marve seed mucilages on physical, sensory and staling properties of sponge cake. J Agric Sci Technol 19:1079-1089

10. Beikzadeh S, Khezerlou A, Jafari SM, Pilevar Z, Mortazavian AM (2020) Seed mucilages as the functional ingredients for biodegradable films and edible coatings in the food industry. Adv Colloid Interf Sci 19:102164

11. Benbettaïeb N, Assifaoui A, Karbowiak T, Debeaufort F, Chambin O (2016a) Controlled release of tyrosol and ferulic acid encapsulated in chitosan-gelatin films after electron beam irradiation. Radiat Phys Chem 118:81-86

12. Benbettaïeb N, Karbowiak T, Brachais C-H, Debeaufort F (2016b) Impact of electron beam irradiation on fish gelatin film properties. Food Chem 195:11-18

13. Błaszczak W, Fornal J, Valverde S, Garrido L (2005) Pressureinduced changes in the structure of corn starches with different amylose content. Carbohydr Polym 61(2):132-140

14. Borah PP, Das P, Badwaik LS (2017) Ultrasound treated potato peel and sweet lime pomace based biopolymer film development. Ultrason Sonochem 36:11-19

15. Bourke P, Ziuzina D, Boehm D, Cullen PJ, Keener K (2018) The potential of cold plasma for safe and sustainable food production. Trends Biotechnol 36:615-626

16. Bourtoom T (2008) Edible films and coatings: characteristics and properties. Int Food Res J 15(3):237-248

17. Bourtoom T (2009) Edible protein films: properties enhancement. Int Food Res J 16(1):1-9

18. Buckow R, Jankowiak L, Knorr D, Versteeg C (2009) Pressure -temperature phase diagrams of maize starches with different amylose contents. J Agric Food Chem 57(24):11510-11516

19. Caillet S, Millette M, Salmieri S, Lacroix M (2006) Combined effects of antimicrobial coating, modified atmosphere packaging, and gamma irradiation on Listeria innocua present in ready-to-use carrots (Daucus carota). J Food Prot 69(1):80-85

20. Cárdenas G, Díaz J, Meléndrez M, Cruzat C (2008) Physicochemical properties of edible films from chitosan composites obtained by microwave heating. Polym Bull 61(6):737748

21. Cárdenas G, Meléndrez M, Cancino AG (2009) Colloidal $\mathrm{Cu}$ nanoparticles/chitosan composite film obtained by microwave heating for food package applications. Polym Bull 62(4):511-524

22. Che L, Li D, Wang L, Özkan N, Chen XD, Mao Z (2007) Effect of high-pressure homogenization on the structure of cassava starch. Int J Food Prop 10(4):911-922

23. Chen G, Ali F, Dong S, Yin Z, Li S, Chen Y (2018) Preparation, characterization and functional evaluation of chitosan-based films with zein coatings produced by cold plasma. Carbohydr Polym 202:39-46

24. Cheng W, Chen J, Liu D, Ye X, Ke F (2010) Impact of ultrasonic treatment on properties of starch film-forming dispersion and the resulting films. Carbohydr Polym 81(3):707-711

25. Cheng X-L, Wan J-Y, Li P, Qi L-W (2011) Ultrasonic/microwave assisted extraction and diagnostic ion filtering strategy by liquid chromatography-quadrupole time-of-flight mass spectrometry for rapid characterization of flavonoids in Spatholobus suberectus. J Chromatogr A 1218(34):5774-5786

26. Coutinho NM, Silveira MR, Fernandes LM, Moraes J, Pimentel TC, Freitas MQ, Silva MC, Raices RS, Ranadheera CS, Borges FO (2018) Processing chocolate milk drink by low-pressure cold plasma technology. Food Chem

27. Dehghani S, Hosseini SV, Regenstein JM (2018) Edible films and coatings in seafood preservation: a review. Food Chem 240:505513

28. El-Dein AE, Khozemy EE, Farag SA, El-Hamed NA, Dosoukey I (2018) Effect of edible co-polymers coatings using $\gamma$-irradiation on Hyani date fruit behavior during marketing. Int J Biol Macromol

29. Falguera V, Quintero JP, Jiménez A, Muñoz JA, Ibarz A (2011) Edible films and coatings: Structures, active functions and trends in their use. Trends Food Sci Technol 22(6):292-303

30. Fan J-M, Ma W, Liu G-Q, Yin S-W, Tang C-H, Yang X-Q (2014) Preparation and characterization of kidney bean protein isolate (KPI)-chitosan $(\mathrm{CH})$ composite films prepared by ultrasonic pretreatment. Food Hydrocoll 36:60-69

31. Farhoodi M, Beikzadeh S (2020) Effect of using cold plasma treatment on the surface and physicochemical properties of starch-chitosan composite film. Iran J Nutr Sci Food Technol 15:103-111

32. Fu Z-Q, Wang L-J, Li D, Wei Q, Adhikari B (2011) Effects of high-pressure homogenization on the properties of starchplasticizer dispersions and their films. Carbohydr Polym 86(1): 202-207

33. Han JH (2014) Edible films and coatings: a review, Innovations in food packaging. Elsevier, pp 213-255

34. Hati S, Patel M, Yadav D (2018) Food bioprocessing by nonthermal plasma technology. Curr Opin Food Sci

35. Heremans K, Smeller L (1998) Protein structure and dynamics at high pressure. Biochim Biophys Acta Protein Struct Mol Enzymol 1386(2):353-370

36. Honarvar Z, Farhoodi M, Khani MR, Mohammadi A, Shokri B, Ferdowsi R, Shojaee-Aliabadi S (2017) Application of cold plasma to develop carboxymethyl cellulose-coated polypropylene films containing essential oil. Carbohydr Polym 176:1-10

37. Kang HJ, Won MY, Lee SJ, Min SC (2015) Plasticization and moisture sensitivity of potato peel-based biopolymer films. Food Sci Biotechnol 24(5):1703-1710

38. Kasemwong K, Ruktanonchai UR, Srinuanchai W, Itthisoponkul T, Sriroth K (2011) Effect of high-pressure microfluidization on the structure of cassava starch granule. Starch-Stärke 63(3):160 170

39. Kawai K, Fukami K, Yamamoto K (2007) State diagram of potato starch-water mixtures treated with high hydrostatic pressure. Carbohydr Polym 67(4):530-535

40. Kaya S, Kaya A (2000) Microwave drying effects on properties of whey protein isolate edible films. J Food Eng 43(2):91-96

41. Kim H-S, Choi H-S, Kim B-Y, Baik M-Y (2010) Characterization of acetylated corn starch prepared under ultrahigh pressure (UHP). J Agric Food Chem 58(6):3573-3579

42. Kim S, Yang S-Y, Chun HH, Song KB (2018) High hydrostatic pressure processing for the preparation of buckwheat and tapioca starch films. Food Hydrocoll 81:71-76

43. Kraśniewska K, Gniewosz M (2012) Substances with antibacterial activity in edible films - a review. Pol J Food Nutr Sci 62(4):199 206

44. Kuan Y-H, Bhat R, Patras A, Karim AA (2013) Radiation processing of food proteins - a review on the recent developments. Trends Food Sci Technol 30(2):105-120

45. Kulisiewicz L, Baars A, Delgado A (2007) Effect of high hydrostatic pressure on structure of gelatin gels. Bull Pol Acad Sci Techn Sci 
46. Lacroix M, Smoragiewicz W, Jobin M, Latreille B, Krzystyniak K (2000) Protein quality and microbiological changes in aerobicallyor vacuum-packaged, irradiated fresh pork loins. Meat Sci 56(1): 31-39

47. Lacroix M, Le T, Ouattara B, Yu H, Letendre M, Sabato S, Mateescu M, Patterson G (2002) Use of $\gamma$-irradiation to produce films from whey, casein and soya proteins: structure and functionals characteristics. Radiat Phys Chem 63(3-6):827-832

48. Li H, Liu E-T, Chan FY, Lu Z, Chen R (2011) Fabrication of ordered flower-like $\mathrm{ZnO}$ nanostructures by a microwave and ultrasonic combined technique and their enhanced photocatalytic activity. Mater Lett 65(23-24):3440-3443

49. Li W, Bai Y, Mousaa SA, Zhang Q, Shen Q (2012) Effect of high hydrostatic pressure on physicochemical and structural properties of rice starch. Food Bioprocess Technol 5(6):2233-2241

50. Lian Z, Zhang Y, Zhao Y (2016) Nano-TiO2 particles and high hydrostatic pressure treatment for improving functionality of polyvinyl alcohol and chitosan composite films and nano-TiO2 migration from film matrix in food simulants. Innovative Food Sci Emerg Technol 33:145-153

51. Liu Y, Wang S, Lan W, Qin W (2019) Development of ultrasound treated polyvinyl alcohol/tea polyphenol composite films and their physicochemical properties. Ultrason Sonochem 51:386-394

52. Lou Z, Wang H, Li J, Zhu S, Lu W, Ma C (2011) Effect of simultaneous ultrasonic/microwave assisted extraction on the antioxidant and antibacterial activities of burdock leaves. J Med Plants Res 5(22):5370-5377

53. Macwan A, Joshi B, Macwan A (2018) Edible coating and irradiation of sapota fruit: a concise review. IJCS 6(3):1908-1910

54. Majzoobi M, Shahbazi M, Farahnaky A, Rezvani E, Schleining G (2013) Effects of high pressure homogenization on the physicochemical properties of corn starch, InsideFood Symposium, pp 33-35

55. Majzoobi M, Seifzadeh N, Farahnaky A, Mesbahi G (2015) Effects of sonication on physical properties of native and crosslinked wheat starches. J Texture Stud 46(2):105-112

56. Marcet Manrique I, Álvarez C, Paredes García-Viniegras B, Rendueles de la Vega M, Díaz Fernández JM (2017) Transparent and edible films from ultrasound-treated egg yolk granules. Food Bioprocess Technol

57. Marcuzzo E, Peressini D, Debeaufort F, Sensidoni A (2010) Effect of ultrasound treatment on properties of gluten-based film. Innovative Food Sci Emerg Technol 11(3):451-457

58. Mason T (1998) Power ultrasound in food processing - the way. Ultrasound in food processing 105

59. McClements DJ (1995) Advances in the application of ultrasound in food analysis and processing. Trends Food Sci Technol 6(9): 293-299

60. Misra N, Patil S, Moiseev T, Bourke P, Mosnier J, Keener K, Cullen P (2014) In-package atmospheric pressure cold plasma treatment of strawberries. J Food Eng 125:131-138

61. Molinaro S, Cruz-Romero M, Sensidoni A, Morris M, Lagazio C, Kerry JP (2015) Combination of high-pressure treatment, mild heating and holding time effects as a means of improving the barrier properties of gelatin-based packaging films using response surface modeling. Innovative Food Sci Emerg Technol 30:15-23

62. Moussa D, Brisset J-L (2003) Disposal of spent tributylphosphate by gliding arc plasma. J Hazard Mater 102(2-3):189-200

63. Murrieta-Martínez C, Soto-Valdez H, Pacheco-Aguilar R, TorresArreola W, Rodríguez-Felix F, Márquez Ríos E (2018) Edible protein films: Sources and behavior. Packag Technol Sci 31(3): $113-122$

64. Nguyen L (2011) In: HQ Zhang, GV Barbosa-Cánovas, VM Balasubramaniam, CP Dunne, DF Farkas, JTC Yuan. Nonthermal Processing Technologies for Food: 3-19
65. Oh YA, Roh SH, Min SC (2016) Cold plasma treatments for improvement of the applicability of defatted soybean meal-based edible film in food packaging. Food Hydrocoll 58:150-159

66. Ouattara B, Sabato S, Lacroix M (2001) Combined effect of antimicrobial coating and gamma irradiation on shelf life extension of precooked shrimp (Penaeus spp.). Int J Food Microbiol 68(1-2):1-9

67. Ouattara B, Giroux M, Yefsah R, Smoragiewicz W, Saucier L, Borsa J, Lacroix M (2002a) Microbiological and biochemical characteristics of ground beef as affected by gamma irradiation, food additives and edible coating film. Radiat Phys Chem 63(3-6): 299-304

68. Ouattara B, Sabato S, Lacroix M (2002b) Use of gammairradiation technology in combination with edible coating to produce shelf-stable foods. Radiat Phys Chem 63(3-6):305-310

69. Pankaj SK, Keener KM (2017) Cold plasma: Background, applications and current trends. Curr Opin Food Sci 16:49-52

70. Pankaj SK, Bueno-Ferrer C, Misra N, O'Neill L, Tiwari B, Bourke P, Cullen P (2014) Physicochemical characterization of plasmatreated sodium caseinate film. Food Res Int 66:438-444

71. Pilevar Z, Bahrami A, Beikzadeh S, Hosseini H, Jafari SM (2019) Migration of styrene monomer from polystyrene packaging materials into foods: Characterization and safety evaluation. Trends Food Sci Technol 91:248-242

72. Reimbert CG, Minzoni A, Smyth N (1996) Effect of radiation losses on hotspot formation and propagation in microwave heating. IMA J Appl Math 57(2):165-179

73. Rodriguez-Turienzo L, Cobos A, Diaz O (2012) Effects of edible coatings based on ultrasound-treated whey proteins in quality attributes of frozen Atlantic salmon (Salmo salar). Innovative Food Sci Emerg Technol 14:92-98

74. Sablani SS, Dasse F, Bastarrachea L, Dhawan S, Hendrix KM, Min SC (2009) Apple peel-based edible film development using a high-pressure homogenization. J Food Sci 74(7):E372-E381

75. Saricaoglu FT, Tural S, Gul O, Turhan S (2018) High pressure homogenization of mechanically deboned chicken meat protein suspensions to improve mechanical and barrier properties of edible films. Food Hydrocoll 84:135-145

76. Scholtz V, Pazlarova J, Souskova H, Khun J, Julak J (2015) Nonthermal plasma - a tool for decontamination and disinfection. Biotechnol Adv 33(6):1108-1119

77. Shahbazi M, Majzoobi M, Farahnaky A (2018) Physical modification of starch by high-pressure homogenization for improving functional properties of $\mathrm{k}$-carrageenan/starch blend film. Food Hydrocoll 85:204-214

78. Shaili T, Abdorreza MN, Fariborz N (2015) Functional, thermal, and antimicrobial properties of soluble soybean polysaccharide biocomposites reinforced by nano TiO2. Carbohydr Polym 134: 726-731

79. Shao Z, Zhou W, Zhu Z (2012) Advanced synthesis of materials for intermediate-temperature solid oxide fuel cells. Prog Mater Sci 57(4):804-874

80. Sheikhi Z, Mirmoghtadaie L, Khani MR, Farhoodi M, Beikzadeh S, Abdolmaleki K, Kazemian-Bazkiaee F, Shokri B, ShojaeeAliabadi S (2020) Physicochemical characterization of argon plasma-treated starch film. J Agric Sci Technol In press

81. Sifuentes-Nieves I, Hernández-Hernández E, Neira-Velázquez G, Morales-Sánchez E, Mendez-Montealvo G, Velazquez G (2018) Hexamethyldisiloxane cold plasma treatment and amylose content determine the structural, barrier and mechanical properties of starch-based films. Int J Biol Macromol

82. Song X, Zhou C, Fu F, Chen Z, Wu Q (2013) Effect of highpressure homogenization on particle size and film properties of soy protein isolate. Ind Crop Prod 43:538-544

83. Stolt M, Oinonen S, Autio K (2000) Effect of high pressure on the physical properties of barley starch. Innovative Food Sci Emerg Technol 1(3):167-175 
84. Sun Y, Sun C.Y, Chen G (2012) Effect of ultrasound treatment on properties of soy proteins film, Applied Mechanics and Materials. Trans Tech Publ, pp. 513-516

85. Swatland H, Barbut S (1999) Sodium chloride levels in comminuted chicken muscle in relation to processing characteristics and Fresnel reflectance detected with a polarimetric probe. Meat Sci 51(4):377-381

86. Takala P, Salmieri S, Vu K, Lacroix M (2011) Effects of combined treatments of irradiation and antimicrobial coatings on reduction of food pathogens in broccoli florets. Radiat Phys Chem 80(12):1414-1418

87. Tang J, Feng H, Lau M (2002) Microwave heating in food processing. Adv Bioprocess Eng 1:1-43

88. Tappi S, Gozzi G, Vannini L, Berardinelli A, Romani S, Ragni L, Rocculi P (2016) Cold plasma treatment for fresh-cut melon stabilization. Innovative Food Sci Emerg Technol 33:225-233

89. The D.P, Debeaufort F, Voilley A, Luu D (2009) Biopolymer interactions affect the functional properties of edible films based on agar, cassava starch and arabinoxylan blends. J Food Eng 90(4):548-558

90. Vallons KJ, Arendt EK (2010) Understanding high pressureinduced changes in wheat flour-water suspensions using starchgluten mixtures as model systems. Food Res Int 43(3):893-901

91. Vieira MGA, da Silva MA, dos Santos LO, Beppu MM (2011) Natural-based plasticizers and biopolymer films: A review. Eur Polym J 47(3):254-263

92. Vittadini E, Carini E, Chiavaro E, Rovere P, Barbanti D (2008) High pressure-induced tapioca starch gels: physico-chemical characterization and stability. Eur Food Res Technol 226(4):889-896

93. Vu KD, Hollingsworth RG, Salmieri S, Takala P, Lacroix M (2012) Development of bioactive coatings based on $\gamma$-irradiated proteins to preserve strawberries. Radiat Phys Chem 81(8):1211-1214
94. Wang B, Li D, Wang L-J, Chiu YL, Chen XD, Mao Z-H (2008) Effect of high-pressure homogenization on the structure and thermal properties of maize starch. J Food Eng 87(3):436-444

95. Wang B, Li D, Wang L-J, Liu Y-H, Adhikari B (2012) Effect of highpressure homogenization on microstructure and rheological properties of alkali-treated high-amylose maize starch. J Food Eng 113(1):61-68

96. Wang Z, Sun X-X, Lian Z-X, Wang X-X, Zhou J, Ma Z-S (2013) The effects of ultrasonic/microwave assisted treatment on the properties of soy protein isolate/microcrystalline wheat-bran cellulose film. J Food Eng 114(2):183-191

97. Wang Z, Zhang N, Wang H-Y, Sui S-Y, Sun X-X, Ma Z-S (2014) The effects of ultrasonic/microwave assisted treatment on the properties of soy protein isolate/titanium dioxide films. LWTFood Sci Technol 57(2):548-555

98. Wang Z, Zhou J, Wang X-X, Zhang N, Sun X-X, Ma Z-S (2014) The effects of ultrasonic/microwave assisted treatment on the water vapor barrier properties of soybean protein isolate-based oleic acid/stearic acid blend edible films. Food Hydrocoll 35:51-58

99. WHO (1981) Wholesomeness of irradiated food. Report of a Joint FAO/IAEA/WHO Expert Committee

100. Zhang S, Yu Y, Xiao C, Wang X, Lei Y (2014) Effect of ultraviolet irradiation combined with chitosan coating on preservation of jujube under ambient temperature. LWT-Food Sci Technol 57(2):749-754

101. Zhong T, Huang R, Sui S, Lian Z, Sun X, Wan A, Li H (2015) Effects of ultrasound treatment on lipid self-association and properties of methylcellulose/stearic acid blending films. Carbohydr Polym 131:415-423

Publisher's Note Springer Nature remains neutral with regard to jurisdictional claims in published maps and institutional affiliations. 